\title{
ANALISIS MODEL PEMBELAJARAN PROBING PROMPTING TERHADAP KEMAMPUAN KONSEP BELAJAR FISIKA PESERTA DIDIK
}

\author{
Ina Rostiana ${ }^{1}$, Nana $^{2}$ \\ Program Studi Pendidikan Fisika, Universitas Siliwangi \\ email: inarostiana06@gmail.com
}

\begin{abstract}
Abstrak. Penelitian ini bertujuan untuk mengetahui pengaruh model pembelajaran probing prompting terhadap kemampuan konsep belajar peserta didik pada pembelajaran fisika. selain itu, penelitian ini menggunakan metode study pustaka yang mana peneliti mencari dan menggabungkan materi dari referensi serta sumber informasi dari buku, jurnal maupun yang lainnya. Hasil dari penelitian ini adalah bahwa dengan menggunaan model probing prompting dapat meningkatkan pemahaman konsep belajar fisika pada peserta didik dengan nilai presentase yang meningkat, dari sebelum dilakukan tes dan setelah dilakukan tes.
\end{abstract}

Kata Kunci: Model Probing Prompting, Peserta Didik, Fisika.

\section{PROBING PROMPTING LEARNING MODEL ANALYSIS OF STUDENT PHYSICS LEARNING CONCEPT ABILITY}

\author{
Ina Rostiana ${ }^{1}$, Nana $^{2}$ \\ Department of Physics Eduaction, Universitas Siliwangi \\ email: inarostiana06@gmail.com
}

\begin{abstract}
This study aims to determine the effect of the probing prompting learning model on the ability of students' learning concepts in learning physics. In addition, this study uses a literature study method in which researchers search for and combine material from references and sources of information from books, journals and others. The result of this study is that by using the probing prompting model, it can improve the understanding of the concept of learning physics in students with an increased percentage value, from before the test and after the test.
\end{abstract}

Keywords: Prompting Probing Model, Students, Physics.

\section{PENDAHULUAN}

Berbagai komponen pembelajaran harus berfungsi secara optimal untuk mendapatkan hasil berupa pengusaan kompetensi oleh peserta didik sehingga tujuan daripada pembelajaran tersebut tercapai. Oleh karena itu, belajar membutuhkan stimulus yang baik, lingkungan yang nyaman dan mendukung, serta cara-cara belajar yang membangkitkan minat sehingga terbebas dari rasa jenuh, bosan, dan keterpaksaan.

Komponen yang paling penting dalam suatu pembelajaran salah satunya adalah metode pembelajaran. Seorang pendidik harus memiliki tujuan terhadap tercapainya suatu metode pembelajaran pada proses pembelajaran. setiap mata peelajaran memiliki metode, strategi, pendekatan serta model yang efektif dan efisien untuk mencapai suatu tujuan.

Pelajaran Fisika merupakan salah satu cabang ilmu pengetahuan alam. Fisika merupakan disiplin ilmu yang mempelajari tentang struktur alam dan menjelaskan fenomena tersebut secara struktur dan teoritis yang komprehensif dalam bentuk matematika. Produk ilmiah dihasilkan dari proses memahami konsep fisika. (Poreni, dkk, 2019).

Dalam proses pembelajaran fisika tentunya sering dijumpai kendala. Menurut Poreni dalam Didi (2019), "untuk mengatasi masalah dalam pembelajaran fisika guru harus mampu mengenal berbagai model pembelajaran yang tentunya harus disesuaikan dengan materi yang diajarkan”. Maka dari itu guru perlu memilih model pembelajaran dengan pertimbangan yang matang. 
Maka dari itu peneliti berupaya untuk mengatasi permasalahan yang ada terhadap pembelajaran fisika dengan menggunakan metode pembelajaran Probing Prompting. Metode pembelajaran Probing Prompting Learning (PPL) dapat meningkatkan tanggung jawab pada siswa tentang hal-hal yang dipelajari dengan cara yang menyenangkan (Dewi \& Kocimaheni, 2019). Sedangkan menurut Reza Syehma Bahtiar dalam Kariani (2020) menambahkan menurut arti katanya, Probing adalah penyelidikan dan pemeriksaan sedangkan Prompting berarti mendorong atau menuntun.

Metode Probing Prompting ini diterapkan dengan memberikan pertanyaan-pertanyaan. Sehingga jika mata pelajaran fisika diberikan pertanyaanpertanyaan oleh pendidik maka peserta didik akan terpancing oleh pertanyaan yang diberikan. Sehingga peserta didik akan terus mencari sumber dan mencoba memahami konsep fisika.

Kebanyakan dari peserta didik, menganggap bahwa mata pelajaran fisika merupakan salah satu mata pelajaran yang sulit untuk dipahami. Padahal hanya dengan memahami konsep saja pelajaran Fisika akan lebih mudah. Ketika suatu materi pengajaran belum dipahami, sebaiknya peserta didik dan pendidik terus mencoba ntuk lebih memahami materi tersebut. Sehingga peserta didik mampu lebih memahami konsep dari setiap mata pelajaran yang belum dipahami.

Selain itu, pada materi fisika peserta didik sering mengalami miskonsepsi. Miskonsepsi dipandang sebagai entitas yang stabil dan digunakan untuk berlogika atau bernalar untuk peristiwa yang sama tapi berbeda konteks. Teori miskonsepsi membagi miskonsepsi menjadi tiga kualitas. Pembagian itu berdasarkan seberapa dalam miskonsepsi itu tertanam dalam cara berpikir siswa dan kecenderungan untuk menghilangkannya. Tiga pembagian kualitas miskonsepsi adalah: (a) miskonsepsi tercampur dengan konsepsi ilmiah yang guru coba ajarkan dalam kelas, (b) miskonsepsi sangat tertanam dalam cara berpikir siswa. Kualitas miskonsepsi seperti itu bisa tertanam dengan alasan waktu dan usaha dalam menyusun konsepsi. Pembagian miskonsepsi yang terakhir adalah (c) miskonsepsi yang sulit dihilangkan. (Sujarwanto, 2019).

Menurut Bahtiar (2020) mengatakan bahwa metode Metode probing promting erat kaitannya dengan keterampilan bertanya. Keterampilan bertanya harus dikuasai oleh guru sehingga saat kegiatan belajar mengajar di kelas, pertanyaan diberikan kepada siswa memiliki makna yang mudah dipahami oleh siswa. Keterampilan bertanya erdiri dari keterampilan bertanya dasar dan keterampilan bertanya lanjut.

Menurut Ngalimun (dalam Jatmiko, 2017:165) model pembelajaran Probing Prompting adalah pembelajaran dengan cara guru menyajikan serangkaian pertanyaan yang sifatnya menuntun dan menggali gagasan siswa sehingga terjadi proses berpikir yang mampu menghubungkan pengetahuan dan pengalaman siswa dengan pengetahuan baru yang sedang dipelajari, selanjutnya siswa mengkontruksikan konsep, prinsip, dan aturan menjadi pengetahuan terbaru, dengan demikian pengetahuan baru tidak diberitahukan.

Jika peserta didik mengalami miskonsepsi pada mata pelajaran fisika, maka pendidik harus menyiapkan pertanyaan yang mampu mempengaruhi pemahaman konsep pada peserta didik. Sehingga ketika peserta didik mengalami miskonsepsi maka pendidik harus meluruskan konsep tersebut agar lebih terarah dalam pembelajaran. Dengan adanya metode ini, antara pendidik dan peserta didik akan saling bertanya satu sama lain untuk memecahkan suatu permaslahan materi fisika.

Menurut Lasmo dalam mutmainnah (2017) kelebihan dari teknik probing-prompting adalah dapat mendorong keterlibatan siswa, meningkatkan keberhasilan, dan menciptakan lingkungan pembelajaran yang positif dan aman secara emosional dan dapat mempermudah siswa melakukan akomodasi dan membangun pengetahuannya sendiri.

Sehingga dengan menggunakan model probing prompting ini, untuk mencapai suatu tujuan pembelajaran peserta didik termotivasi mengemukakan pendapat dalam proses pembelajarannya.

\section{METODE PENELITIAN}

Metode penelitian yang digunakan adalah metode literatur integratif, yaitu peneliti melakukan penelaahan literatur melalui proses meninjau, mengkritik dan mensisntesis literatur representatif mengenai suatu topik dengan menggabungkan materi dari berbagai sumber seperti buku, jurnal dan situs web. Dengan metode literatur ini merupakan salah satu pendukung untuk menemukan ide dari sumber yang berkaitan dengan topik penelitian.

\section{HASIL DAN PEMBAHASAN}

Terdapat beberapa langkah pembelajaran yang dapat dilakukan oleh pendidik ketika menggunakan model pembelajaran Probing Prompting ini. Menurut Susanti dalam Yuaayu (2017) terdapat tujuh langkah pembelajaran probing prompting, diantaranya:

1. Pendidik menghadapkan peserta didik pada situasi yang baru, misalkan dengan memperhatikan gambar, rumus atau situasi yang lainnya yang mengandung permasalahan.

2. Menunggu beberapa saat untuk memberikan kesempatan kepada peserta didik untuk merumuskan jawaban atau melakukan diskusi kecil untuk merumuskannya.

3. Pendidik mengajukan persoalan kepada peserta didik yang sesuai dengan tujuan pembelajaran.

4. Menunggu beberapa saat untuk memberikan kesempatan kepada peserta didik untuk merumuskan jawaban atau melakukan diskusi kecil untuk merumskannya. 
5. Menunjuk salah satu peserta didik untuk menjawab pertanyaan.

6. Jika jawabannya tepat maka pendidik meminta tanggapan kepada peserta didik lain tentang jawaban tersebut untuk meyakinkan bahwa seluruh peserta didik dalam kegiatan belajar terlibat aktif. Namun, jika jawabannya salah, maka guru membuat atau mengajukan pertanyaan baru yang jawabannya merupakan petunjuk dari jalan penyelesaian jawaban. Sampai menemukan jawaban yang benar, sehingga membuat peserta didik berfikir kritis dalam kegiatan pembelajaran.

7. Pendidik mengajukan pertanyaan akhir pada peserta didik yang berbeda untuk lebih menekankan bahwa tujuan pembelajaran tersebut benar-benar telah dipahami oleh seluruh peserta didik.

Pada hasil penelitian yang telah peneliti lain lakukan bahwa pengaruh model Probing Prompting oleh Siscawati Rizki Lasmo (2017) Rata-rata presentase setiap indikator aktivitas belajar dari ketiga pertemuan adalah: visual activities presentase rata-rata $91,57 \%$, oral activities presentase rata-rata $87,61 \%$, listening activities presentase rata-rata $91,19 \%$, writing activities presentase rata-rata $86,97 \%$, motor activities presentase ratarata $85,83 \%$, mental activities presentase rata-rata $80,84 \%$, emotional activities presentase rata-rata $86,30 \%$. Sedangkan rata-rata ketercapaian indikator dari ketiga pertemuan sebesar $85,80 \%$ dengan kriteria tergolong aktif.

Hasil penelitian selanjutnya yaitu dilakukan oleh Nina Trisna, dkk, pada tahun 2019. Menyebutkan bahwa Berdasarkan hasil analisis data dapat disimpulkan bahwa hasil belajar fisika siswa kelas X SMA Negeri 4 Lubuklinggau setelah diterapkan teknik Probing Prompting secara signifikan tuntas. Rata-rata nilai tes akhir siswa sebesar 75,11 dan presentase jumlah siswa yang tuntas sebesar $80,5 \%$.

Selain itu, peneliti lain lakukan dengan hasil analisis data menunjukkan bahwa kemampuan argumentasi mahasiswa setelah perlakuan lebih baik dibandingkan sebelum perlakuan dan terdapat perbedaan signifikan $(\mathrm{Z}=$ 7,397, $\mathrm{p}=0,000$ ) kemampuan argumentasi mahasiswa sebelum dan setelah diterapkan model berpikir induktif dengan metode probing-prompting learning pada materi subgrup. Dengan demikian, penerapan model berpikir induktif dengan metode probing-prompting learning pada materi subgrup efektif untuk meningkatkan kemampuan argumentasi mahasiswa. Penelitian ini dilakukan oleh Lisanul Uswah Sadieda pada tahun 2019 dengan judul artikel Kemampuan Argumentasi Mahasiswa Melalui Model Berpikir Induktif Dengan Metode ProbingPrompting Learning.

Hal ini dapat diketahui bahwa dengan menggunakan model Probing Prompting pada konsep pembelajaran Fisika dapat meningkatkan kemampuan belajar peserta didik dengan nilai presentase yang meningkat dari sebelum diberikan tes dan setelah diberikan tes.

\section{KESIMPULAN}

Dari hasil analisis beberapa artikel penelitian dapat disimpulkan bahwa dengan metode Probing Prompting dapat meningkatkan pemahaman konsep Fisika peserta didik Dengan hasil persentase belajar yang meningkat dari hasil tes awal dengan tes akhir yang telah dilakukan.

\section{DAFTAR PUSTAKA}

Bahtiar, Reza Syehma. (2020). Metode ProbingPrompting dalam Meningkatkan Kemampuan Melengkapi Puisi bagi Siswa Sekolah Dasar. Jurnal Pendidikan. Vol 11 (1).

Jatmiko. 2017. Perbedaan Pengaruh Model Pembelajaran Probing Prompting dan SQ4R Siswa Madrasah Aliyah. Jurnal Gammah, vol 2 No, Hal:165.

Kariani, N. K., Kt, D. B., Semara, N., \& Ardana, I. K. (2014). Model Problem Based Learning Menggunakan Metode Probing - Promting Berpengaruh terhadap Hasil Belajar IPA Siswa Jurusan Pendidikan Guru Sekolah Dasar , FIP Universitas Pendidikan Ganesha. Jurnal Mimbar PGSD Universitas Pendidikan Ganesha, 2(1).

Lasmo, Siscawati Rizki., dkk. (2017). Pengaruh Model Pembelajaran Inkuiri Terbimbing Dengan Teknik Probing-Prompting Terhadap Aktivitas Dan Hasil Belajar Fisika di SMA. Jurnal Pembelajaran Fisika. Vol 6 (2). Hal 162-167.

Mutmainnah, S., Ali, M., Napitupulu, N.D. (2014). Penerapan Teknik Pembelajaran ProbingPrompting Untuk Meningkatkan Hasil belajar Fisika pada Siswa Kelas VIII A SMP Negeri 1 Banawa Tengah. JPFT 2(1).

Poreni, Anna Christi., dkk. (2019). Pengaruh Model Discovery Learning Dengan Teknik Probing Prompting Terhadap Hasil Belajar Fisika Kelas Xi Sma Negeri 1 Makassar. JSPF. 15 (2). ISSN. $1858330 \mathrm{X}$.

Sadieda, Lisanul Uswah. (2019). Kemampuan Argumentasi Mahasiswa Melalui Model Berpikir Induktif Dengan Metode Probing-Prompting Learning. Jurnal Pendidikan Matematika. 14 (1).

Sujarwanto, Eko. (2019). Pemahaman Konsep dan Kemampuan Penyelesaian Masalah dalam Pembelajaran Fisika. Difraction 1(1).

Susanti, Elsa. (2017). Penerapan Model Pembelajaran Probing Prompting Untuk Meningkatkan Kemampuan Berpikir Kritis Matematis Siswa Kelas XI IPA MAN 1 Kota Bengkulu. Jurnal Pendidikan Matematika Raflesia. Vol 2 (1).

Trisna, Nina., dkk. (2019). Model Direct Instruction Dengan Teknik Probing Prompting : Dampak Terhadap Hasil Belajar Fisika Siswa Kelas X Sma Negeri 4 Lubuklinggau Tahun Pelajaran 2018/2019. Jurnal Pendidikan Ilmu Fisika. Vol 1 (1). 